\title{
Investigation of Social Networking Function in the Development of Viral Marketing
}

\author{
Ali Bonyadi Naeini ${ }^{1} \&$ Erfan Sohrabi ${ }^{2}$ \\ ${ }^{1}$ Assistant Professor, Iran University of Science and Technology (IUST), Iran \\ ${ }^{2}$ MSc. of Technology Management- Iran University of Science and Technology (IUST), Iran \\ Correspondence: Ali Bonyadi Naeini, Assistant Professor, Iran University of Science and Technology (IUST), \\ Iran. E-mail: bonyadi@iust.ac.ir/megapox9@gmail.com
}

Received: March 10, 2016

Accepted: March 27, 2016

Online Published: April 10, 2016

doi:10.5539/mas.v10n6p112

URL: http://dx.doi.org/10.5539/mas.v10n6p112

\begin{abstract}
This study, to assess the functioning of social networks in the spread of viral marketing that took place in this particular case the country's IT industry were investigated. Therefore, the researcher has used the survey questionnaire and the population in this study, users of social page of Rahpooyan Rayan Gostar Bartar Company on Facebook. To test the validity of research tools, test reliability and validity study, Cronbach's alpha was used. According to Cochran sampling, sample size among Facebook users in the social network of Rahpooyan Rayan Gostar Bartar Company, 384 were identified. In this study, to determine the component that is used to analyze the hierarchy of the elite group of elite people in the study were 60 people, as a result, it was found there was a significant relationship between social media marketing and how its success that leads to the purchase of goods and services.According to the results of this study, it was found that there is a significant relationship between social network marketing to draw attention to animation, attractive image for color and design, attractive slogans, self-marketing, social networking, use of celebrities, the use of symbols and its impact on the purchase of goods. These results indicate that perhaps one of the most important reasons is to prevent people, goods or services in respect of their social networks, distrust of it. Trust, creates social space that organizations can operate in that space.
\end{abstract}

Keywords: social networking, viral marketing, Facebook

\section{Introduction}

Viral marketing is meant to facilitate the free provision allowing individuals to transfer it to others. The main purpose of viral marketing, spreading the message to as many people possible, without having to spend money for advertising. In fact, this type of marketing, such as the proliferation of the virus itself and the client is released. The most common way to do this type of Internet marketing, especially social networks to increase the number of Internet users is growing more important. Social networks can be connected communities of people with the aim of defining the structure of linked nodes with more than one type (Vidal et al. 2011). The social network of technical complexities down to provide benefits in the use of web creativity, and in social interaction, have a share in the specialty, content sharing and publishing information and various discussions and to create a network of trading partners. To reduce the time for innovation in marketing and sales, reduce risk and cost and increase flexibility recommend the use of social networking sites are in marketing and sales. Viral marketing in social networks based on the core functionality of each firm to be formed and it will lead to more effective management of marketing in the organization. In this research, look for applications in the field of marketing are done. In Iran, little research has focused, has studied the impact of Facebook in our lives and its role in marketing. 
The main objective of this research include: helping managers to make effective use of marketing using social networking in the enterprise space, the introduction of social networking and its applications, particularly in advertising, marketing, comparing the social networks or in other words other traditional methods of marketing, in publishing marketing messages to attract more audiences. The methodology used in this study is a survey method. The survey is used primarily in studies in which a person is considered to be the unit of analysis.

\section{Theoretical Foundations}

Internet is the most important and most controversial issues in trade and business education. Development of high speed internet marketing, so that the stone is slow research and publication of the results. It is known that commercial institutions to rapidly evolving and dynamic deployment of new internet and thus should be the most extensive media know that numerous changes in the field of marketing and development has created. It affects many areas of marketing, including segmenting and targeting are cited, pricing, customer service and customer relationship management, packaging, marketing communications, promotion, distribution channels and value chain, global marketing and brand (Hosseini et al., 2008). E-mail marketing is the use of electronic channels to communicate with customers, in order to spread marketing messages in this regard. The term internet marketing, generally means: Achieving corporate objectives, by meeting and exceeding the needs of our customers, so better than the competition by using the internet and other digital technologies. (Shipside, 2002). Extensive use of social software technologies or applications that are used for social purposes, especially web 2, a relatively new phenomenon (Shao and Palin 2008 quoted by Hamid et al., 2009). Social media communities connect people with different motivations, a structure containing more than one type of communication nodes, defined (quoted by Vidal et al., 2011). Social media source varies greatly: some of them, like Facebook, to support various student groups have been developed in American universities, while others such as LinkedIn, aimed at developing greater professional focus calls or the job of working through the network (quoted by Vidal et al., 2011). Social networks through SNS social networking sites generally offered on the Internet. Social networking technologies are simple to learn and use and in many areas are used to improve the speed and effectiveness of communications (Schlenkrich and Sohi 2012). Social networking sites are very popular online destinations that offer users a simple way to create and maintain relationships with others and publish information in a place called social network. Social networking features as the largest part of social media, including: Users of social networks, opportunities for sharing information including email, chat, instant messaging, videos, bugs, to share files and photos, the social network for database users are, therefore, they can easily find a friend, social network users are opportunities for the development of online profiles and adjust their social networks, the social networks are free, most social networks according to user feedback, with the possibility of re-evaluation and up again. Social networks, it is possible to reset the privacy of its users is available, so users can share what they are and share them decide, and so on. (Ferdig 2007, Murat and Chakir 2010). Social networking companies, regardless of size, can enhance the brand value of a company with just a visitor. Usually takes six months to get results from SEO and visit your site to be added. Faster ways to use social network marketing practices. People on social networks are courting, social activities and raise their networks online. Social networks are infinitely high traffic they create. Internet advertising can be in two categories is that with the advent of social networks have changed very fast. (Ahsan and Sogail 2012).

\subsection{Research Background}

Hosseini et al 2008 studied the effect of Internet Marketing exporters in the export performance of the industrial sector. The population of the investigation, exporters in the sample. Yousefi et al 2007 examined the status of sports marketing through the Internet in Iran. Iman Khan 2008 studied consumer behavior in e-mail marketing. Investigation of consumer body structure, the introduction of the digital environment and plan the formation and 
impact of mental models in the digital environment, and also the communication behavior of consumers in the digital environment, in this article have been investigated. Prasad et al 2001 due to Internet marketers in competitive marketing and export performance were evaluated. Bengtson et al. 2007. Effects of small business internet marketing business in the international study. Kilpelainen et al., 2012 social networks to improve the teaching of social studies in remote areas were studied. The results suggest that the use of educational media and other methods of distance learning, has various advantages both for students and for teachers.

\subsection{Research Model}

According to the existing relationships we will use the following model.

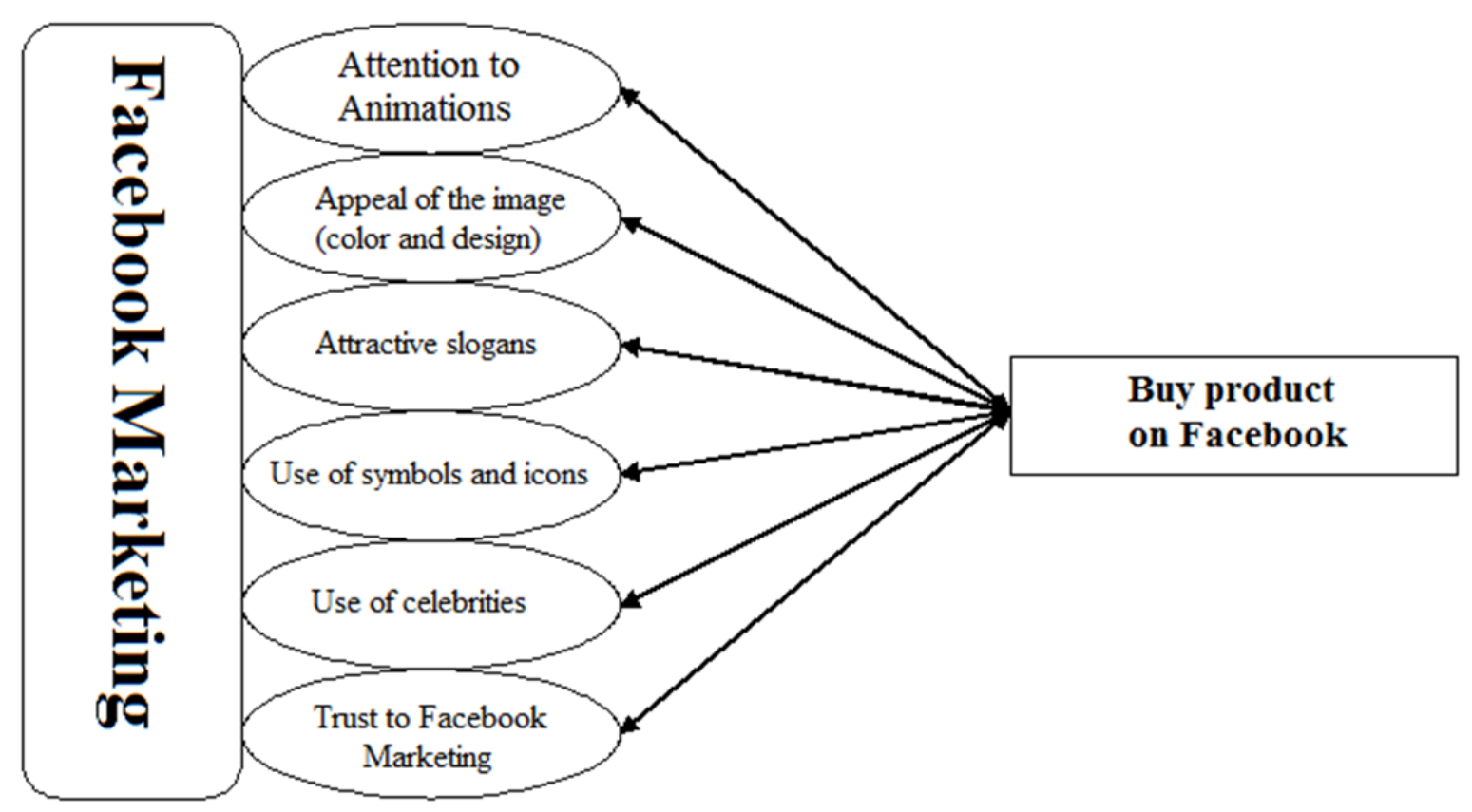

Figure 1. Research Model

\subsection{Hypothesis}

1. There is a significant relationship between marketing and animations of interest.

2. There is a significant relationship between visual appeal and appeal to the audience.

3. There is a significant relationship between the use of symbols and signs of interest.

4. There is a significant relationship between the use of celebrities in marketing and attracting the attention of the audience.

5. There is a significant relationship between attractiveness and appeal to the audience in marketing slogan.

\subsection{Society and Statistical Sample}

Statistical society of research, a set of persons, objects, plants, places, events and things in general refers to one or more common characteristics or features. The amount of adjectives and less common features, wider society and the attributes or features are more common, society will be more limited. In the process of research, study population should be clearly defined and precise dimensions and specifications. Therefore, in this study population, Internet users inside the country and the dynamic of the social network Facebook of Rahpooyan Rayan Gostar Bartar Company (both male and female) and age class between 14 and 74 years, which has not been announced the exact number. 


\subsection{Data Collection Method}

In this study, the method of questionnaire was used to collect data. The questionnaire has 22 questions, most of which Likert scale developed and designed by experts. It is worth noting that this questionnaire study, regular type 1 and package that leads to ease of extraction results and facilitate accountability. The questionnaire, in addition to individual characteristics, the main research variables have been studied.

\section{Findings}

The first study to analyze the data collected in the field, via questionnaire, extraction and set the table. Then all the data using SPSS software in both descriptive and inferential statistics were used. Then, using statistical techniques and operational research MCDM including IHP variables are consistent with the methodology and data collection, analysis and research questions to be answered. To do fast this research, Excel 2007 and Expert Choice Software used. In this study, to determine the component that is used to analyze the hierarchy of the elite group of elite people in this study are 60. The questionnaires were distributed and collected the people working in the IT market. Of the 400 questionnaires returned due to incomplete responses of some 384 questionnaires completed questionnaires were received and based on the analysis of data was discussed.

\section{Studying Demographic Characteristics of the Sample}

First, it be discussed to describe the demographic characteristics of the sample, the descriptive statistics and demographic information (age, education, gender, organizational posts) are shown in Table 1.

Table 1. Demographic Features

\begin{tabular}{lcrr}
\hline & & Frequency & Percent \\
\hline Age & $35-45$ & 70 & 0.18 \\
& $46-55$ & 140 & 0.37 \\
Gender & $56-65$ & 172 & 0.45 \\
& Man & 326 & 0.85 \\
Education Level & Female & 58 & 0.15 \\
& Associate Degree & 77 & 0.20 \\
& BS & 230 & 0.60 \\
& MS & 51 & 0.13 \\
& PhD & 26 & 0.07 \\
\hline
\end{tabular}

Profile of respondents in terms of age were evaluated and shown in Figure 2.

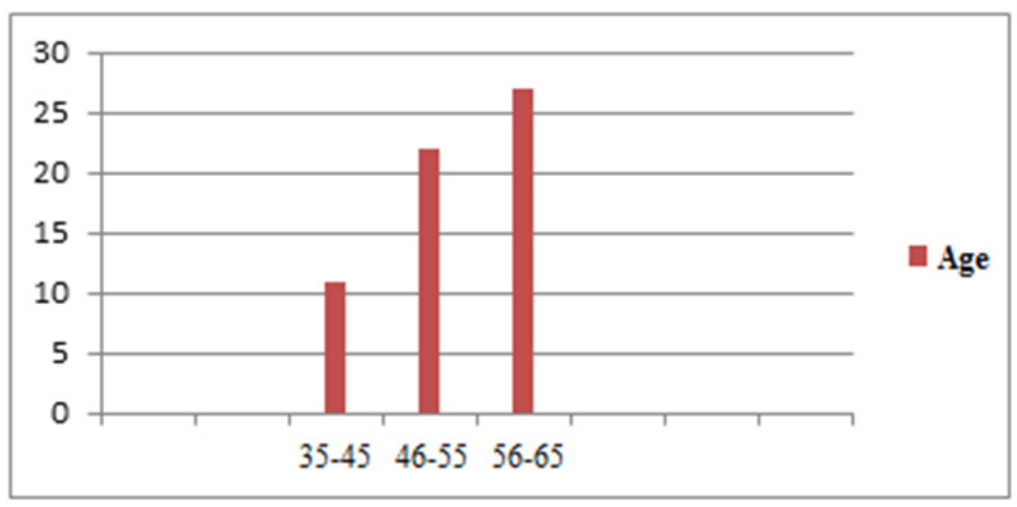

Figure 2. Diagram of the frequency of respondents by age

Respondents' status according the education level is shown in Figure 3. 


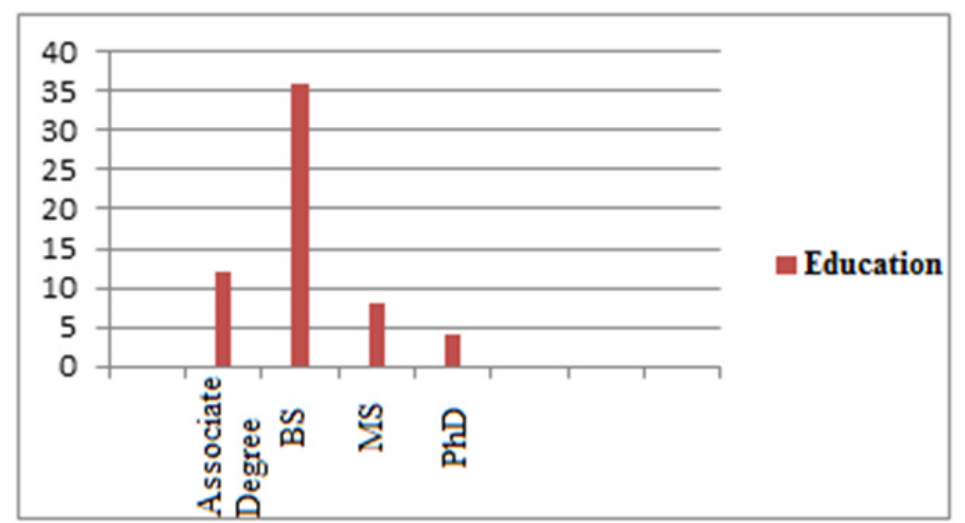

Figure 3. Frequency diagram relating to the Status of respondents in terms of education level

So the frequency of subjects on the basis of gender can be seen in Figure 4.

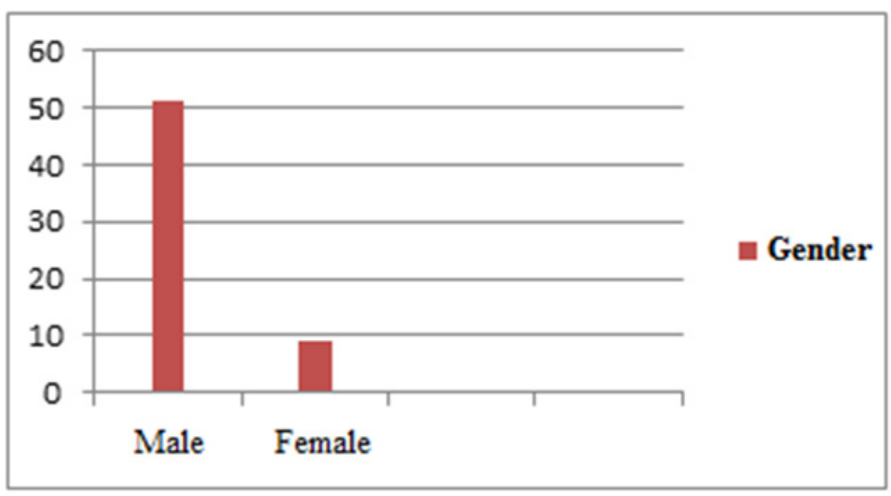

Figure 4. Frequency distribution relating to the status of respondents in terms of gender

Finally, with the help of SPSS software to Cronbach's alpha. The value of the coefficient of 0.70 is higher, the reliability of the research is confirmed. According to Cronbach's alpha coefficient that is equal to 0.816, confirmed the reliability of the research.

Table 2. Cronbach's alpha of 36 questions

\begin{tabular}{ll}
\hline Number of questions & Cronbach's alpha coefficients \\
\hline 36 & 0.816 \\
\hline
\end{tabular}

Pairwise comparison matrices 384 decision-makers using the geometric mean is calculated as follows. In this way, after a pairwise comparison matrix, the geometric mean of each row of the matrix is calculated; in the second part of the split-column matrix of each of its components are normalized to the total components available. The new column matrix produced by the matrix of the index weight is desired. The mathematical form of this approach can be seen in the following equation.

$$
\left[\begin{array}{cccc}
a_{11} & \cdot & \cdot & a_{1 n} \\
\cdot & \cdot & \cdot & \cdot \\
\cdot & \cdot & \cdot & \cdot \\
a_{n 1} & \cdot & \cdot & a_{n n}
\end{array}\right] \stackrel{1}{\rightarrow}\left[\begin{array}{c}
\sqrt[n]{a_{11} \ldots a_{1 n}} \\
\cdot \\
\cdot \\
\sqrt[n]{a_{11} \ldots a_{1 n}}
\end{array}\right]=\left[\begin{array}{c}
\pi_{1} \\
\cdot \\
\cdot \\
\pi_{2}
\end{array}\right] \stackrel{2}{\rightarrow}\left[\begin{array}{c}
\frac{\pi_{1}}{\sum_{\mathrm{i}=1}^{\mathrm{n}} \pi_{\mathrm{i}}} \\
\cdot \\
\pi_{\mathrm{n}} \\
\sum_{\mathrm{i}=1}^{\mathrm{n}} \pi_{\mathrm{i}}
\end{array}\right]=\left[\begin{array}{c}
\mathrm{W}_{1} \\
\cdot \\
\cdot \\
\mathrm{W}_{\mathrm{n}}
\end{array}\right]
$$

In this study 7 main criteria to prioritize social networking function in the development of viral marketing known as paired comparisons integrated matrix of 384 decision makers in Table 3. 
Table 3. Pairwise comparison matrix of the main criteria in the development of viral marketing function of social networks

\begin{tabular}{|c|c|c|c|c|c|c|c|}
\hline \multicolumn{8}{|c|}{ Compare the relative importance with respect to: Olaviat bandi karkard shabake haye ejtemae } \\
\hline & Animation & Rang va Ta & biat sh ! & dva & Afrad Mash & & Kharid Kali \\
\hline Animation & & 2.5 & 1.6 & 1.4 & 2.1 & 3.3 & 1.6 \\
\hline Rang va Tarahi & & & 1.2 & 2.5 & 2.3 & 2.7 & 2.3 \\
\hline Jazabiat shoar & & & & 1.9 & 1.5 & 2.2 & 2.5 \\
\hline Namad va Sambol & & & & & 1.7 & 1.8 & 1.6 \\
\hline Afrad Mashhor & & & & & & 2.5 & 2.2 \\
\hline Etemad & & & & & & & 1.0 \\
\hline Kharid Kala & Incon: 0.08 & & & & & & \\
\hline
\end{tabular}

After building the model in Expert Choice program and enter pairwise comparison matrices, the weight of criteria and sub criteria as shown below, respectively. In Figure 5, the priority of social networking function in the development of viral marketing by Expert Choice Software is shown.

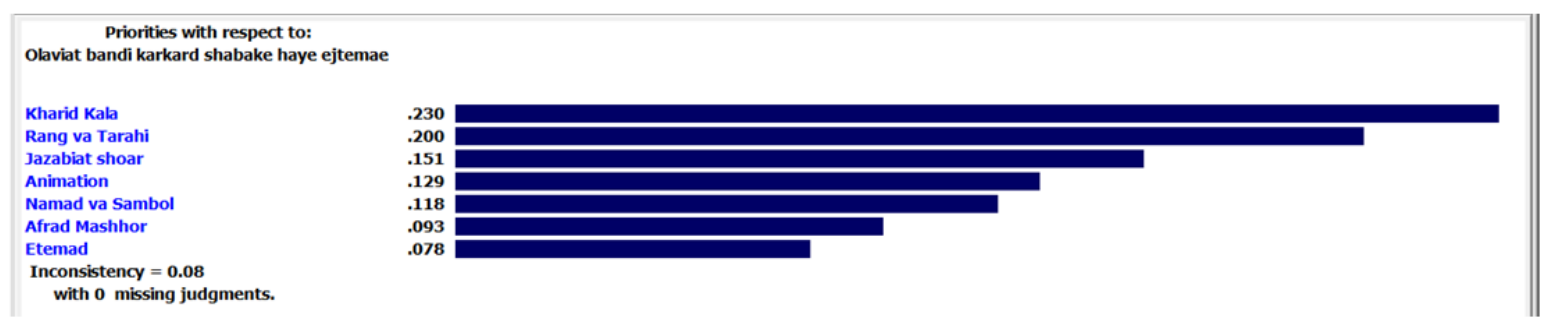

Figure 5. Weights of the main criteria in the development of viral marketing, social networking functions using the Expert Choice Software

As seen in Table 5, the index of purchasing goods with the relative weight of 0.230 is most important. Thus, the index of the main criteria in the development of functioning social networks and viral marketing is most effective colors and design relative weight of 0.200 is the next priority. Measure the relative weight of 0.078 celebrities is the last priority. Inconsistency of pairwise comparison 0.08 achieved because less than 0.2 the compatibility of these comparisons is acceptable.

Table 5. Prioritizing performance indicators Social Networks in the development of viral marketing

\begin{tabular}{llll}
\hline Row & Main criteria & Weight & Priority \\
\hline 1 & Attention to the animation marketing & 0.129 & 4 \\
2 & Attractiveness of the image (color and design) in Marketing & 0.200 & 2 \\
3 & Attraction marketing slogans & 0.152 & 3 \\
4 & Use of the symbol in marketing & 0.118 & 5 \\
5 & Unsure of celebrities in marketing & 0.093 & 6 \\
6 & Trust level to marketing & 0.078 & 7 \\
7 & Buy the product of social network & 0.230 & 1 \\
\hline
\end{tabular}

In this study, a total of 36 sub-criteria related to seven key criteria to prioritize social performance indicators in the development of viral marketing known an integrated matrix of pairwise comparison of 384 decision-makers in the following tables.

Relative weight of sub-criteria of attention criteria to animation marketing 


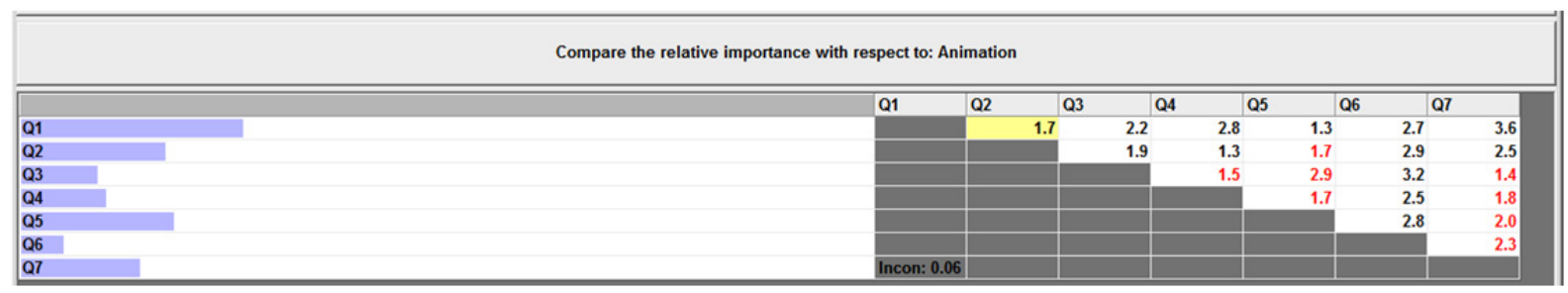

Table 6. Pairwise comparison matrix below standard criteria draw attention to the animation marketing

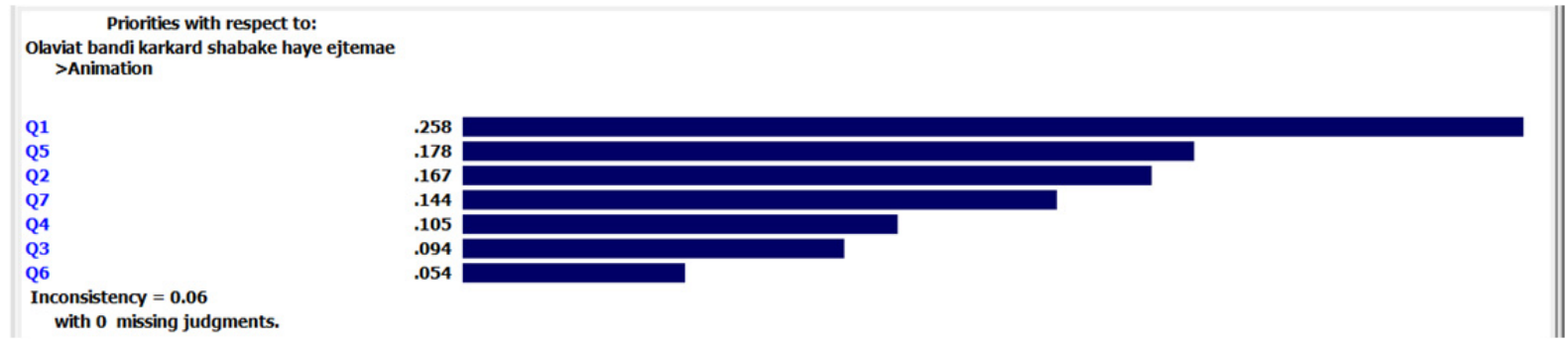

Figure 6. Prioritize the sub-criteria draw attention to the animation marketing standards using Expert Choice

Software

As seen in Figure 6, the first and fifth questions questionnaire weight 0.258 and 0.178 are the most important and top priority. Table 7 standard prioritize the sub-criteria draw attention to the animation marketing is shown.

Table 7. Prioritize the sub-criteria draw attention to the animation marketing

\begin{tabular}{llll}
\hline Row & Question & Weight & Priority \\
\hline 1 & First question & 0.258 & 1 \\
2 & Second question & 0.167 & 3 \\
3 & Third question & 0.094 & 6 \\
4 & Fourth question & 0.105 & 5 \\
5 & Fifth question & 0.178 & 2 \\
6 & Sixth question & 0.054 & 7 \\
7 & Seventh question & 0.144 & 4 \\
\hline
\end{tabular}

Relative weight of sub-criteria of attractiveness of the image (color and design) in marketing

Table 8. Matrix paired comparisons sub-criteria of attractiveness of the image (color and design) in marketing

\begin{tabular}{|c|c|c|c|c|c|c|c|c|}
\hline \multicolumn{9}{|c|}{ Compare the relative importance with respect to: Rang va Tarahi } \\
\hline & Q8 & Q9 & Q10 & Q11 & Q12 & Q13 & Q14 & Q15 \\
\hline Q8 & & 1.4 & 2.2 & 2.4 & 1.3 & 2.7 & 3.6 & 2.5 \\
\hline Q9 & & & 1.5 & 1.6 & 1.6 & 2.9 & 2.2 & 1.2 \\
\hline Q10 & & & & 1.2 & 2.8 & 3.2 & 1.6 & 1.7 \\
\hline Q11 & & & & & 3.2 & 2.8 & 1.7 & 2.5 \\
\hline Q12 & & & & & & 3.5 & 2.8 & 1.6 \\
\hline Q13 & & & & & & & 3.3 & 2.2 \\
\hline Q14 & & & & & & & & 1.5 \\
\hline Q15 & Incon: 0.07 & & & & & & & \\
\hline
\end{tabular}


Priorities with respect to:

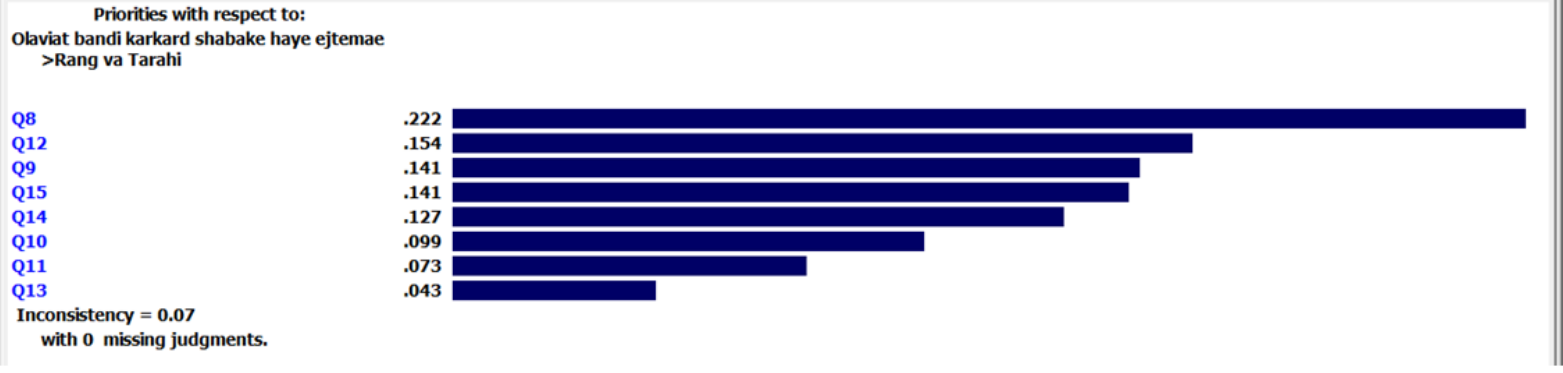

Figure 7. Prioritize sub-criteria of attractiveness of the image (color and design) in marketing using Expert

Choice Software

According to the application, eighth and twelfth questions weights 0.222 and 0.154 are of utmost importance. So, with the first and second top priorities. In Table 9 prioritize sub-criteria of attractiveness of the image (color and design) in marketing is shown, inconsistency of pairwise comparison 0.07 found that when less than 0.10 the compatibility of these comparisons are also acceptable.

Table 9. Prioritize sub-criteria of attractiveness of the image (color and design) in marketing

\begin{tabular}{llll}
\hline Row & Sub-criteria & Weight & Priority \\
\hline 1 & Eighth question & 0.222 & 1 \\
2 & Ninth question & 0.141 & 3 \\
3 & Tenth question & 0.099 & 6 \\
4 & Eleventh question & 0.073 & 7 \\
5 & Twelfth question & 0.154 & 2 \\
6 & Thirteenth question & 0.043 & 8 \\
7 & Fourteenth question & 0.127 & 5 \\
8 & Fifteenth question & 0.141 & 4 \\
\hline
\end{tabular}

Relative weight sub-criteria of attractiveness of the slogans in marketing

Table 10. Pairwise comparison matrix of sub-criteria of attractiveness of the slogans in marketing
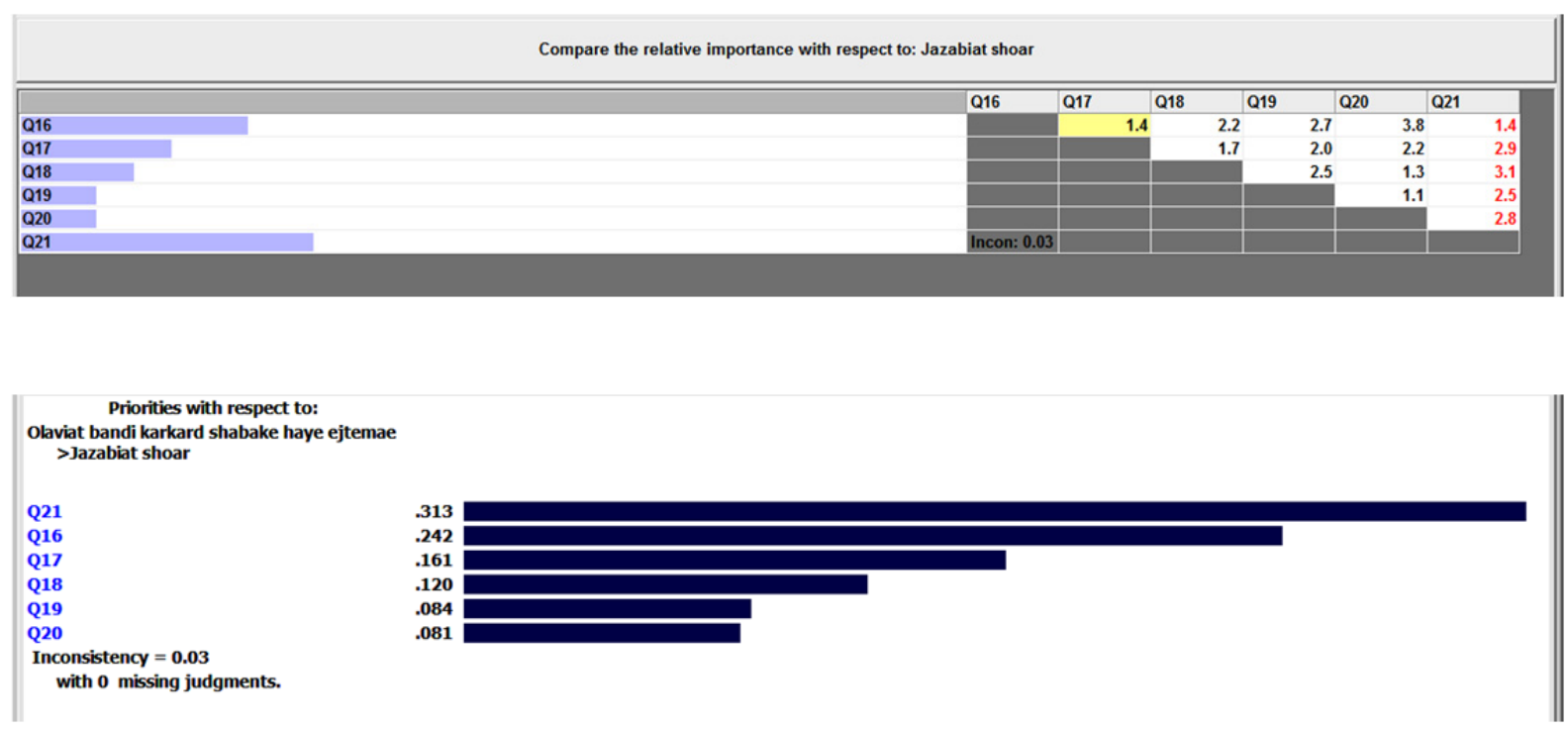

Figure 8. Prioritize sub-criteria of attractiveness of the slogans in marketing using Expert Choice Software

According to the results, twenty first question weighing 0.312 the greatest importance. Question sixteenth and 
seventeenth question of weighing the relative weight of 0.242 and 0.161 in the second priority located on the third priority. Prioritize sub-criteria of attractiveness of the slogans in marketing in Table 11 shown interest in marketing slogans. Inconsistency of pairwise comparison 0.03 found that less than 0.10 the compatibility of these comparisons are also acceptable.

Table 11. Prioritize sub-criteria of reduce latency

\begin{tabular}{llll}
\hline Row & Sub-criteria & Weight & Priority \\
\hline 1 & Sixteen question & 0.242 & 2 \\
2 & Seventeen question & 0.161 & 3 \\
3 & Eighteen question & 0.120 & 4 \\
4 & Nineteen question & 0.084 & 5 \\
5 & Twenty question & 0.081 & 6 \\
6 & Twenty-one question & 0.313 & 1 \\
\hline
\end{tabular}

Relative weight sub-criteria of related to the criteria for use of the symbol and icon in marketing

Table 12. Pairwise comparison matrix of sub-criteria of related to the criteria for use of the symbol and icon in marketing

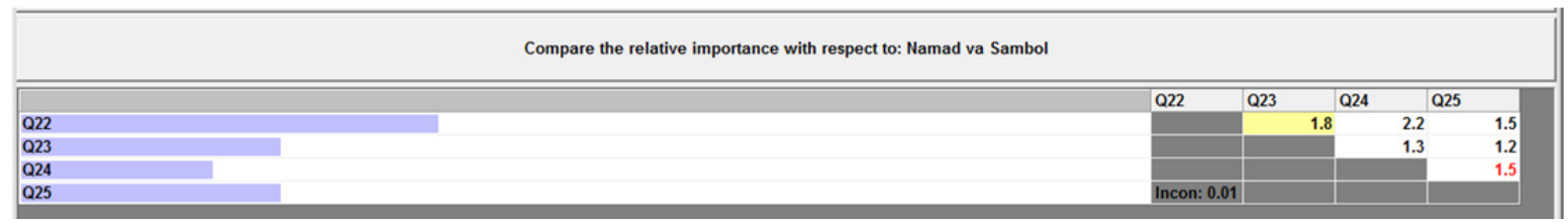

According to the results of the pairwise comparison matrix of indicators related to the questions of the twenty-second and twenty-third sub-criteria weights 0.373 and 0.232 priorities were first and second in the 13 sub-criteria related priorities sub-criteria of related to the criteria for use of the symbol and icon in marketing. Rate incompatibility 0.005 less than 0.10 was obtained. The compatibility matrix also acceptable decisions.

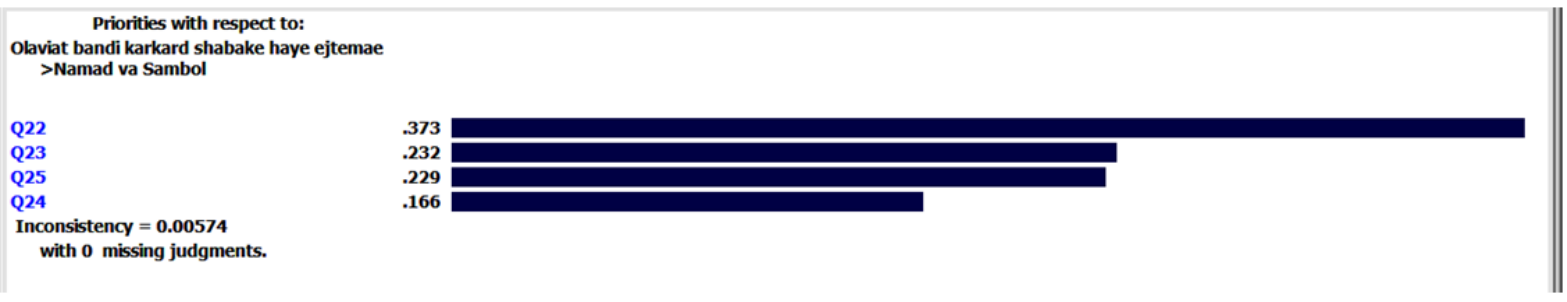

Figure 9. Prioritize sub-criteria of related to the criteria for use of the symbol and icon in marketing using Expert Choice Software

Table 13. Prioritize the sub-criteria related to cost-cutting measures

\begin{tabular}{llll}
\hline Row & Main criteria & Weight & Priority \\
\hline 1 & Twenty two & 0.373 & 1 \\
2 & Twenty three & 0.232 & 2 \\
3 & Twenty four & 0.166 & 4 \\
4 & Twenty five & 0.229 & 3 \\
\hline
\end{tabular}

Relative weight of sub-criteria related to criteria for use of celebrities in marketing 
Table 14. Pairwise comparison matrix of sub-criteria related to criteria for use of celebrities in marketing
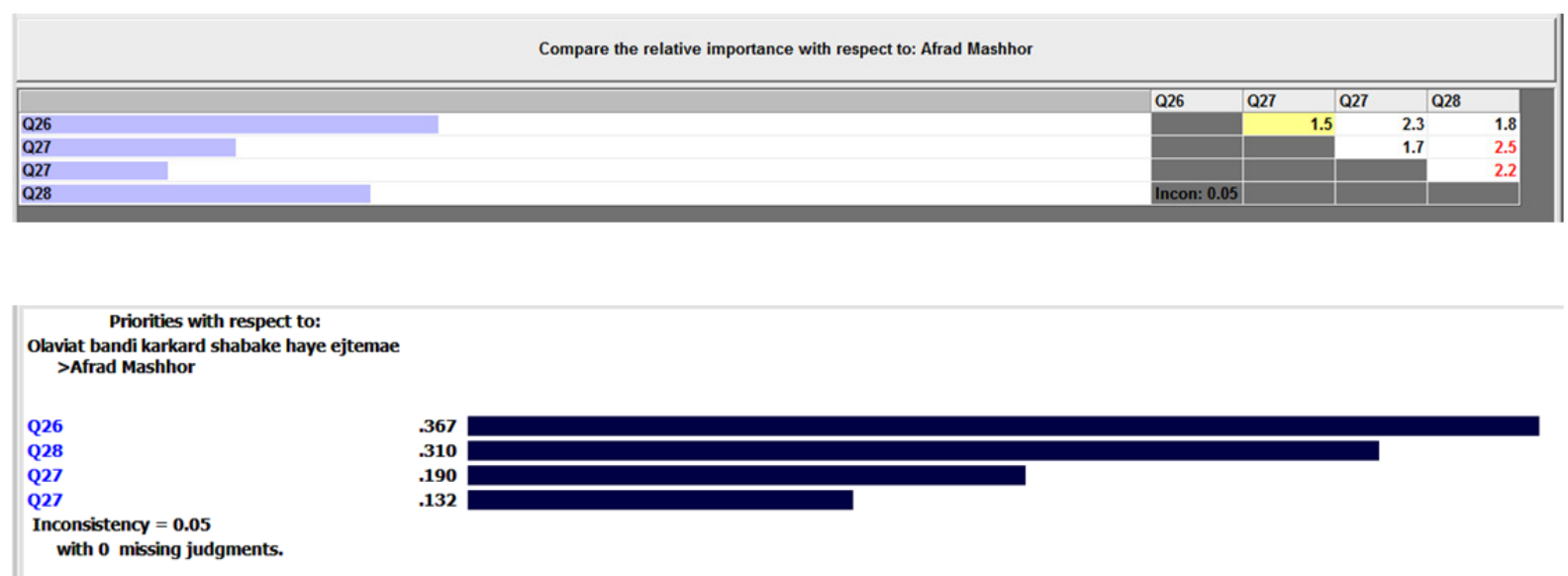

Figure 10. Prioritize the sub-criteria related to criteria for use of celebrities in marketing using Expert Choice Software

Table 15. Prioritize the sub-criteria related to criteria for use of celebrities in marketing

\begin{tabular}{llll}
\hline Row & Main criteria & Weight & Priority \\
\hline 1 & Twenty-six question & 0.367 & 1 \\
2 & Twenty-seven question & 0.190 & 4 \\
3 & Twenty-eight question & 0.132 & 3 \\
4 & Twenty-nine question & 0.310 & 2 \\
\hline
\end{tabular}

According to the results of the pairwise comparison matrix of indicators to measure unsure of celebrities in marketing, twenty-sixth and twenty-ninth sub-criteria questions 0.367 and 0.310 weighing priorities were first and second in the table 15 sub-criteria to prioritize the use of celebrities in marketing is shown. Repugnance rate 0.05 less than 0.10 was obtained. The compatibility matrix is also acceptable decisions.

Relative weight of the sub-criteria of trust criteria

Table 16. Pairwise comparison matrix of the sub-criteria of trust criteria
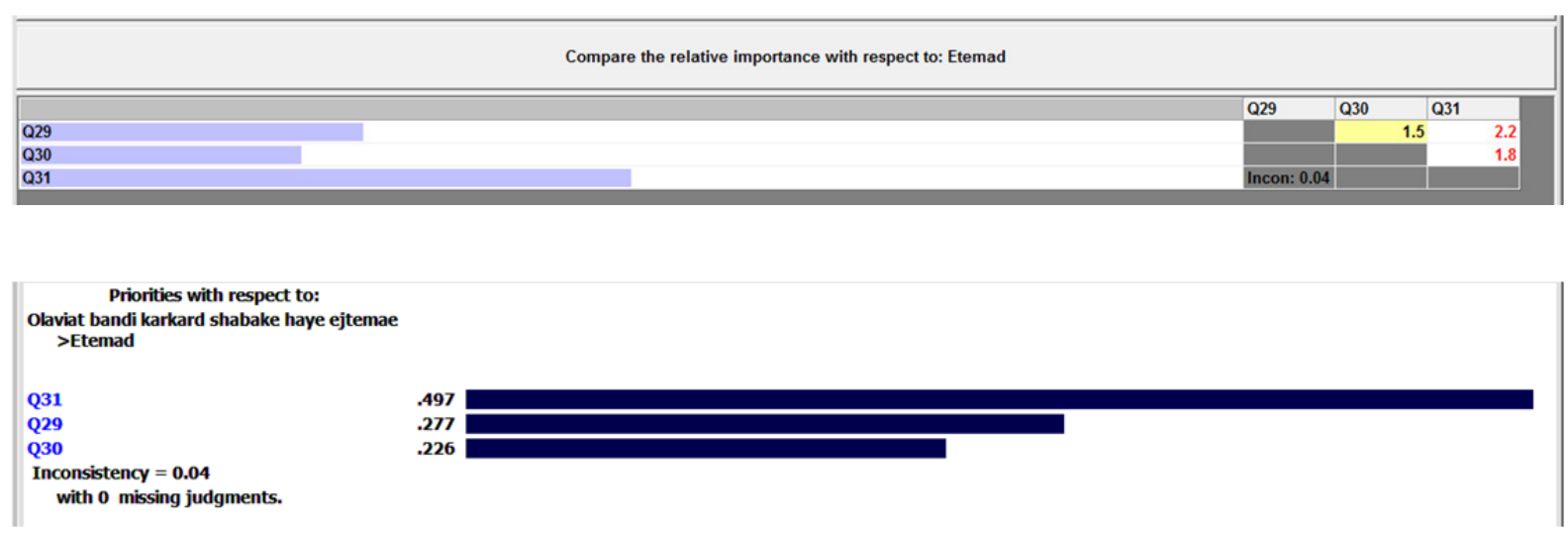

Figure 11. Prioritize the sub-criteria of accuracy trust criteria using Expert Choice Software

The measure of trust, questions the thirty-first and twenty-ninth and thirtieth the weight of 0.497, 0.277 and 0.226 in the first priority, were second and third in the 17 priority sub-criteria to measure trust is shown. The incompatibility rate 0.04 less than 0.10 was obtained. The compatibility matrix also acceptable decisions. 
Table 17. Prioritize the sub-criteria of trust criteria

\begin{tabular}{llll}
\hline Row & Main criteria & Weight & Priority \\
\hline 1 & Twenty-nine question & 0.277 & 2 \\
2 & Thirty question & 0.226 & 3 \\
3 & Thirty-one question & 0.497 & 1 \\
\hline
\end{tabular}

Relative weight of the sub-criteria of buy the product of social network

Table 18. Pairwise comparison matrix of the sub-criteria of buy the product of social network

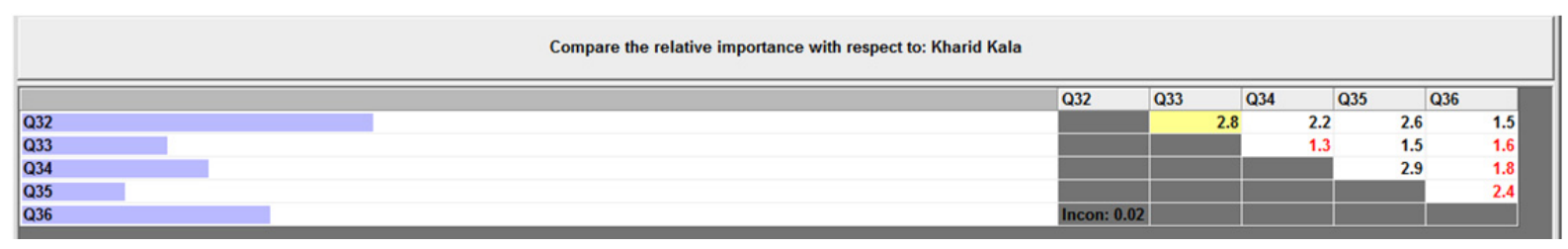

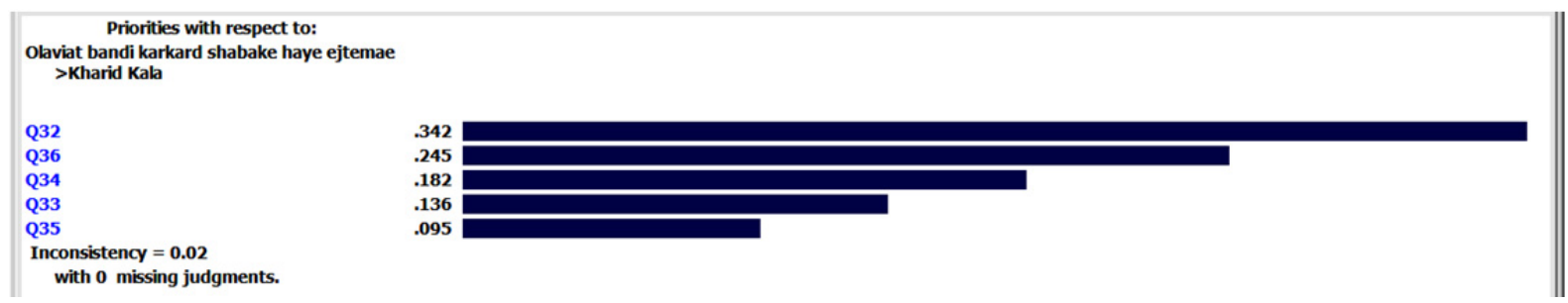

Figure 12. Weight of the sub-criteria of buy the product of social network using Expert Choice Software

According to the application, thirty-second and thirty-sixth sub-questions with weights 0.342 and 0.245 are of utmost importance. The top priorities are first and second. The 19 sub-criteria prioritization criteria for procurement of social networks has shown inconsistency of pairwise comparison 0.02 found that when less than 0.10 the compatibility of these comparisons are also acceptable.

Table 19. Prioritize the sub-criteria of buy the product of social network criteria

\begin{tabular}{llll}
\hline Row & Main criteria & Weight & Priority \\
\hline 1 & Thirty-two question & 0.342 & 1 \\
2 & Thirty-three question & 0.136 & 4 \\
3 & Thirty-four question & 0.182 & 3 \\
4 & Thirty-five question & 0.095 & 5 \\
5 & Thirty-six question & 0.245 & 2 \\
\hline
\end{tabular}

In figure 12 weight and priority of 36 sub-criteria related to social performance indicators in the development of viral marketing using Expert Choice Software shown in their order of importance. 


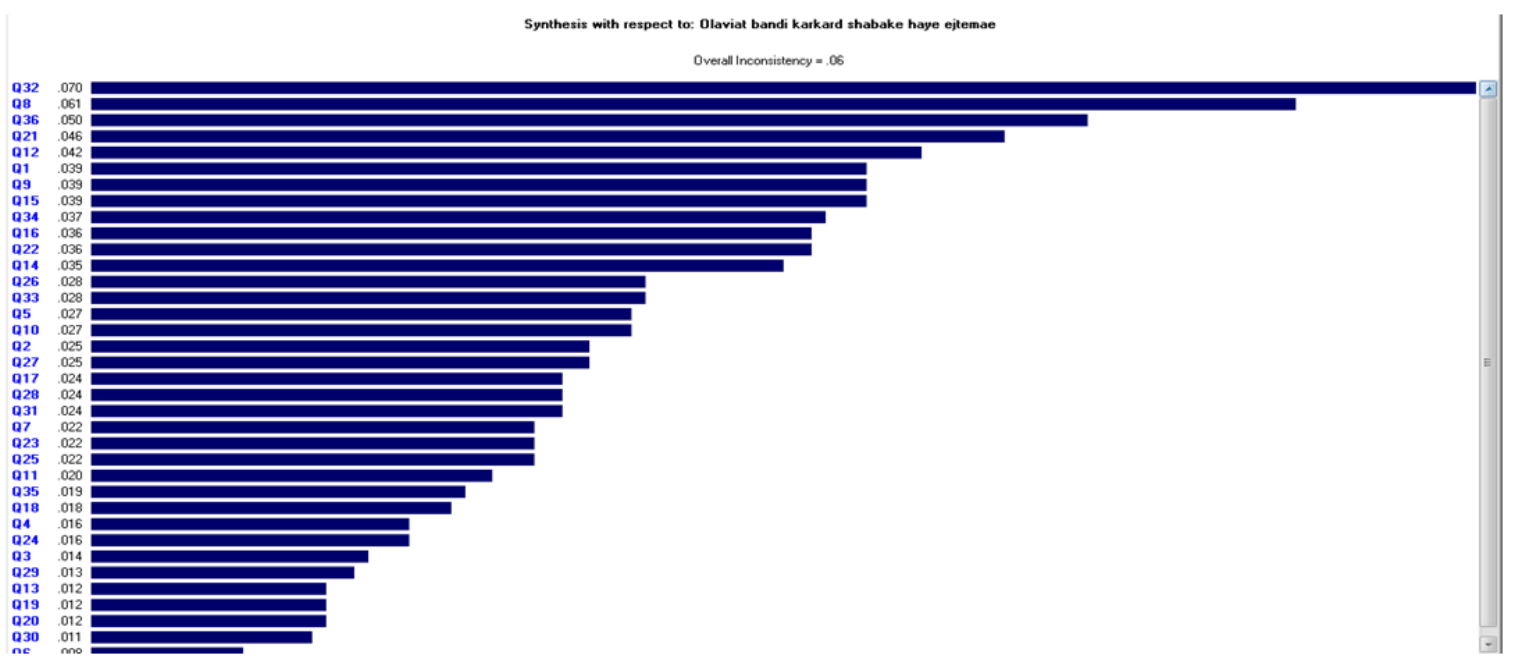

Figure 13. Weight of 36 sub-criteria related to social performance indicators in the development of viral marketing

According to the results of the above, the following criteria related to the thirty-second questions and the eighth in the top rank first and second respectively, have the most impact. The incompatibility rate of 0.06 has been obtained paired comparisons.

\section{Investigation of normal distribution of variables}

In order to analyze the relevant data and choose the kind of test, you must first go to the normality of variables. Because if the variables are normal, will allow the parametric tests and the parametric tests we use. But if you are not normal variables, we used nonparametric tests are only allowed to be. Test is used to assess the normality of variables, is the Kolmogorov-Smirnov test. This test is used when we want to see the data that the variables are normal or not.

H0: The variables have normally distributed.

H1: The variables have not normally distributed.

Table 20. Normally distributed variables

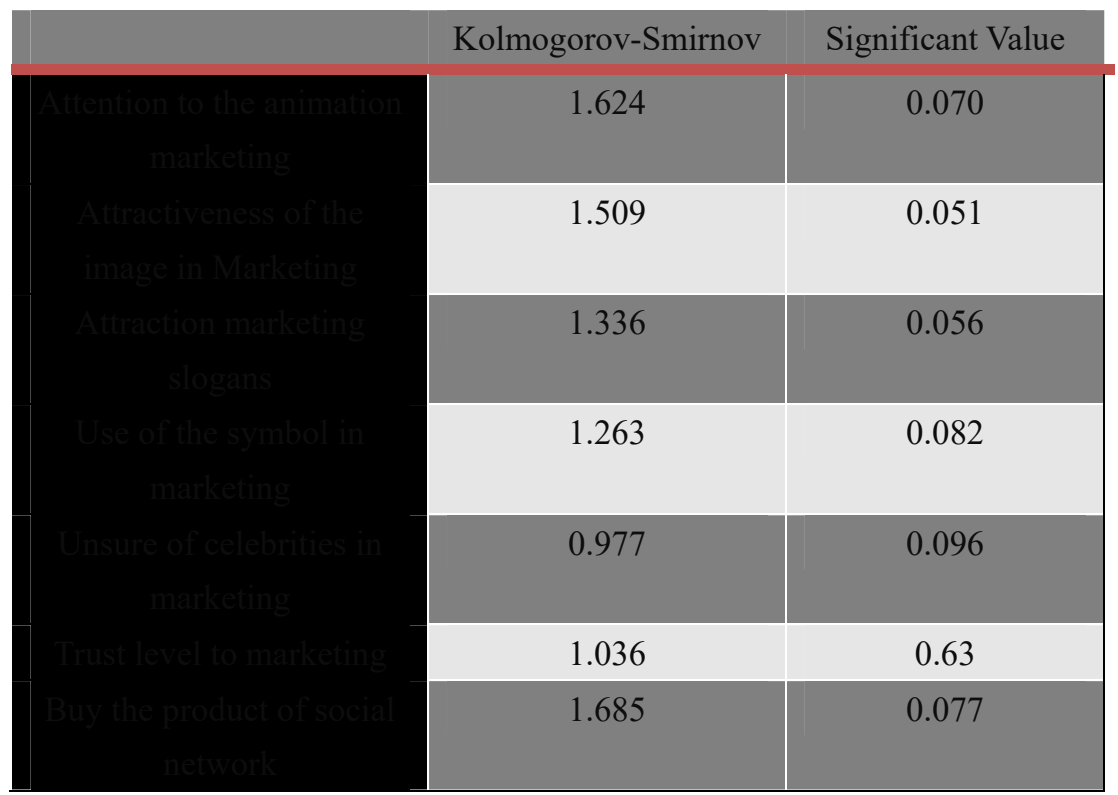

Test distribution is Normal. 
If the resulting number is greater than the significance level $\alpha=0.05$ null hypothesis is accepted and the null hypothesis is rejected and otherwise contrary assumption it is approved. Spss software according to the central limit theorem is considered normal results of the questionnaire, the null hypothesis of normality of variables is approved.

\section{Discussion and Conclusion}

This research was carried out to "determine the priority social networking function in the development of viral marketing." And studies showed that $42.2 \%$ of respondents in a day 2 to 6 hours of Internet use, $74.2 \%$ of them less than 2 hours a day using their Facebook, $28.9 \%$ of people said that the most important reason for their use of Facebook, news is information, $65.1 \%$ of respondents Facebook social network marketing to low and very low rates and $74.7 \%$ of respondents have observed that social network marketing Facebook to low and very low opinion of them has received. The results showed that $78.9 \%$ of respondents to the Facebook social network marketing (marketing group and page) in the low and very little trust, $62.8 \%$ said that the Facebook social network marketing to low levels and very few of them introduce a new product or service, $77 \%$ of respondents believe that Facebook marketing network, low and very low rates encourage them to buy goods or services, $60.5 \%$ believe that the color in marketing social network Facebook (photo or video commercials) to high and very high levels of attention they are involved in, $60.1 \%$ of respondents believe that marketing design (photo or video commercials) on network Facebook, high and very high levels of attention they are involved and $58.6 \%$ said that the photographs for marketing goods or services in the social network Facebook, high and very high rates to attract the experts. According to the study, $70.8 \%$ of respondents believe the teaser video for marketing goods or services in the social network Facebook, high and very high opinion of them has received, $61.7 \%$ believe that the animation for marketing goods or Services included in the social network Facebook to low and very low opinion of them has received, $88 \%$ of respondents are seeing marketing (photo or video commercials) on the social network Facebook, low and very low rates to buy have the goods or services; $63.3 \%$ of respondents believe that the goods or services in the opinions of other users on the social network Facebook, low level and very little for them to buy the product involved, $59.4 \%$ believe that the number of members of a network marketing groups of Facebook, on appeal to them to purchase goods or services, the rate is low and very little role. Also in this study, it was found that $75.3 \%$ of respondents said that the appeal of social networking in marketing slogans Facebook, low level and very little attention to the role; $60.2 \%$ of people believe that the use of symbols and icons and (historic sites, etc.) in social network Facebook marketing, low level and very little to contribute to their attention; $57.8 \%$ of respondents said that the use of celebrities in marketing social network Facebook, low rates and very little to contribute to their attention; $59.4 \%$ believe that due to the characteristics of the social network Facebook, beautiful appearance and very little marketing to low levels in their decision to purchase goods or services online, and $74.7 \%$ of respondents indicated that they affect the marketing of goods or service on the Web Facebook is the low and very low rate makes buying it via the Internet prefer to purchase the goods or services in the market similar products. The results showed that $85.7 \%$ of respondents said that marketing is published in social network Facebook to share their low level and very few others, $70.6 \%$ of respondents believe that social network marketing on Facebook low rates and very few meet the daily needs as well, $43.2 \%$ of respondents, more marketing messages than have seen the image on Facebook and $44 \%$ of respondents believe that the purpose of viewing the page in the social network Facebook marketing, familiarity with the commodity. Following the investigation, it was found that $19 \%$ of respondents stated that most goods or services that the social network Facebook have received, scientific and educational; $26 \%$ believe that the views of users on the product advertised, cause them to trust their Facebook network marketing; $42.2 \%$ of respondents believe that the design of advertising, marketing effectiveness in social network Facebook in buying them, it is more important; $55.2 \%$ believe that to attract the audience, a combination of propaganda is more important and $57.6 \%$ of respondents stated that combined marketing approach, is more effective for the audience. According to studies carried out in this study to use viral marketing in social networks must be provided space in such a way that it will spread to the audience or in other words to share our marketing message urged and it should be made quite an indirect because according to the results obtained in this study, patients entered a partnership in any way for direct or in other words do not help to spread marketing by marketers so to achieve an acceptable success in the spread of the virus or the sharing of marketing and social media marketing message by the audience due to the indirect transmission of the virus is very important to observe the items included: Color marketing social network Facebook (photo or video commercials), design (photo or video commercials) on the social network Facebook, photos on the social network Facebook for marketing goods or services, teaser video for marketing goods or services in social networks Facebook and etc. is necessary. 


\section{References}

Ahsan, H., \& Sohail, C. (2012). Pattern of Facebook usage and its Impact on Academic Performance of University Students: A Gender Based Comparison. Bulletin of Education and Research December, 22(1), 12-19.

Bengisson, M., Hakan, B., \& Vladimir, V. (2007). Integrating the internet and marketing operations. International Small Business, 11(1), 17-22.

Hosseini, A., Ghazizadeh, M., \& Abbasi, H. (2008). The effect of the use of e-mail marketing on the performance of the industrial sector in the year 2000. Sample exporters 22, with emphasis on the Internet. Scholar behavior, 21, 111-121.

Iman, K. N. (2008). Consumer behavior in digital marketing. Journal of Management, V(11), 21-22.

Murat, K., \& Cakir, O. (2010). An applied study on educational use of facebook as a web 1.4 tool: the sample lesson of computer networks and communication. International Journal of Computer Science \& Information Technology (IJCSIT), 1(2), 12-22.

Petrovic, N., Petrovic, D., Jeremic, V., Milenkovic, N., \& Cirovic, M. (2012). Possible educational use of facebook in higher environmental education. ICICTE 2012 Proceedings. 211-261.

Prasad, V., Kanti, Ramamurthy, K., \& Naidu, G. M. (2001). The influence of internetmarketing integration on marketing competencies and export performance. Journal of international marketing, 9(2), 21-144.

Schlenkrich, L., \& Sewry, D. (2011). Factors for Successful Use of Social Networking Sites in Higher Education. Research Article, SACJ No. 29, September. 11-12.

Shipside, S. (2002). Branding on the Internet: New International Marketing Issues. Management Research News, 11(11), 12-61.

Vidal, C., Martinez, J., Fortuno, M., \& Cervera, M. (2011). University Students' Attitudes Towards and Expectations of the Educational Use of Social Networks. RUSC, 2(1), 126-199.

Yousefi, B., \& Taheri, H. S. (2007). The study of sports marketing through the Internet in Iran, with an emphasis on the elements of research in sports sciences, 11, 212.

\section{Copyrights}

Copyright for this article is retained by the author(s), with first publication rights granted to the journal.

This is an open-access article distributed under the terms and conditions of the Creative Commons Attribution license (http://creativecommons.org/licenses/by/3.0/). 